\title{
HYGIENE
}

УДК $613.2-057.87: 316.728$

DOI: $10.26565 / 2617-409 X-2019-3-05$

\section{HYGIENIC FEATURES OF THE DIET OF FOREIGN MEDICAL STUDENTS CONSIDERING THEIR NATIONAL CULTURES}

\author{
Agwu Chigborum Charles, Halyna Holubhycha, Liudmyla Maliarova
}

Mail for correspondence: charleschigborum@gmail.com

\begin{abstract}
Summary: During studying, foreign students undergo many stages of adaptation to new habitats, including adaptations to climatic, social and nutritional features in Ukraine. Foreign students experience difficulties in shaping their diet, following national traditions. They do not always have the right to pick analogues of the usual food products, to cook, and are increasingly fed in fast food.

The aim of the study is to offer corrective measures on the diet of foreign medical students, taking into account the characteristics of national cultures, which depend on the geographical location of the country of residence of students.

To achieve the goal, the following objectives were set: to assess the peculiarities of the diet of students who came from Africa and South Asia from gender perspective; to identify factors that prevent foreign medical students from following the principles of rational nutrition; to develop proposals for correction of eating behavior of students. Methods of research - sociological (questioning and interviewing), analytical, medical-statistical, nonparametric methods of mathematical statistics.

The paper presents data on the quantitative and qualitative composition of food products that respondents used during the day and the diet of foreign medical students who came to study from the countries of Africa and South Asia.

It has been established that nutrition of students is not balanced in structure, mode, protein, fat, carbohydrate ratio in both groups.

The author shows the main barriers that, according to students, impede them to eat rationally.

Obtaining data allowed to make recommendations for the correction of eating behavior by foreign students, which consists in conducting information companies among foreign students for the promotion of healthy eating, taking into account the data of a permanent residence; informing the students about WHO recommendations for healthy eating; conducting constant monitoring of eating behavior of students using the proposed questionnaire.
\end{abstract}

Key words: foreign students, balanced nutrition, diet, quantitative and qualitative indicators, healthy lifestyle

\section{Information about author}

Agwu Chigborum Charles, Student

3 Course, V.N. Karazin Kharkiv National University, Svobody sq. 6, Kharkiv, Ukraine, 61022, charleschigborum@gmail.com

Halyna Holubhycha, Assistant of department of Hygiene and Social Medicine, V.N. Karazin Kharkiv National University, Svobody sq. 6, Kharkiv,
Ukraine, 61022 ; Junior scientific worker of the Department of the Scientific Organization of Medical Assistance to Schoolchildren and Adolescents of the State Enterprise "Institute for the Protection of Children and Adolescent Health of the National Academy of Medical Sciences of Ukraine" Yuvileinyi Avenue 52a, Kharkiv, Ukraine, 61153, galj6566@gmail.com, https://orcid.org/0000-0001-7832-20591
Liudmyla Maliarova, Assistant of department of Hygiene and Social Medicine, V.N. Karazin Kharkiv National University Svobody sq. 6, Kharkiv, Ukraine, 61022, E-mail 1.v.maliarova@karazin.ua, https://orcid.org/ 0000-0002-7902-7016 


\section{Introduction}

Ukraine is fast becoming a land of dreams. The recent UNIAN report is an evidence of this with its statistical report showing that the number of foreign students in Ukraine is also growing steadily. As of January 1, 2019, 66,310 students. Last year (2018), there were 64 thousand. In the top ten, the number of foreign students in Ukraine includes India (almost 11 thousand students from this country), Azerbaijan (7.5 thousand), Morocco (5.8 thousand), Turkmenistan (4.5 thousand), Nigeria (3.5 thousand), as well as Georgia, Jordan, Egypt, Turkey and Uzbekistan. [1] In the period of their studies, international students undergo many stages of adaptation to new living conditions, including adaptation to climatic, social and most importantly nutritional adaptation in Ukraine. Foreign students experience difficulties in shaping their diet and adhering to national cultures. Students are considered to be a high risk group because at this stage of development young people are under the powerful influence of two important factors: active physiological reorganization of the organism and intensive socialization of the individual. Intensive mental and physical activity associated with the educational process, puts the students in an increased demands [2]. Changing the nature of food (consumption of highly refined products, products of long-term storage); disturbance of the diet, sedentary lifestyle (hypokinesia, hypodynamia) can lead to diseases of the digestive system, nervous stress and neurosis, fatigue and poor academic performances. The students of medical schools should promote healthy eating and be of great examples for others [3].

The use of artificial trans fats in foods that are part of such products as margarine and "light" oils, crackers, biscuits and cakes, donuts and french fries, almost all semi-finished products (dough, pizza, meat and fish products), as well as packaged, ready-to-eat foods (chips, snacks, crackers, nuts, popcorn, sauces, mayonnaises, most kinds of chocolate and ice cream, candy and waffles). But the trans fat consumption is harmful, even in small quantities. When blood transfats transfats, they change the structure of cell membranes, which become less permeable to nutrients and the selection of products of vital activity. The cells are in the conditions of energy hunger. This leads to a disorder of metabolism, diseases of the nervous system, the cardiovascular system, liver, cholesterol, obesity, and others [4,5].

According to scientists from Odessa Medical University, nutrition of foreign students is unbalanced for the energy value, the ratio of proteins, fats and carbohydrates, which creates a metabolic basis for the formation of alimentarydependent pathology. The attention of scientists, doctors and professors of various fields of health

science has been drawn to the problems of the health of students. To analyze the nutritional ration

of foreign students, determine the factors and propose corrective measures on the diet of foreign medical students, taking into account the characteristics of national cultures, which depend on the geographical location of the country of residence of students. To offer correctional measures to the diet of foreign medical students [6].

\section{Materials and methods}

The aim of the study is to offer corrective measures on the diet of foreign medical students, taking into account the characteristics of national cultures, which depend on the geographical location of the country of residence of students.

The subject of the study is the diet of foreign medical students taking into account the characteristics of national cultures.

Subject of research - the results of questioning and interviewing foreign students of the 3rd year of the medical faculty.

Volume of research is 100 foreign students, of which 56 students came from Africa, (Group 1 below), and 44 students who came to study in Southern Asia (Group 2 below).

Methods of research: - sociological (questioning and interviewing), medicalstatistical, analytical, nonparametric methods of mathematical statistics.

To achieve the goal and solve problems, students, in cooperation with the scientists of the department "Hygiene and Social Medicine" of the medical faculty of the V.N. Karazin National University. was developed a questionnaire "Assessment of individual nutrition". The questionnaire consists of the passport part, which specifies the name, date and the date of birth of the respondent, his anthropometric data - height, body 
weight, and body mass index. In addition, the questionnaire included questions about compliance with the "Norms of physiological needs in nutrients and energy for the adult population of Ukraine (in accordance with the recommendations of FAO / WHO)". That is, students determined the individual metabolic indexes based on the level of physical activity and compared their rates with the recommended daily intake of energy and nutrients (proteins, fats, carbohydrates).

In the second part of the questionnaire, students were asked to record all the products they consume during the day during breakfast, lunch, dinner and snacks in grams. Subsequently, with the help of Nutritionology [7], respondents calculated the amount of proteins, fats, carbohydrates, the total number of calories consumed during each meal and the total daily intake, and were able to compare the findings with normative indicators and draw conclusions about their eating habits.

In the final part of the questionnaire, students compared the caloric intake of each meal in a percentage of the caloric content of consumed foods over the course of the day with normative indicators.
The materials of the questionnaire allowed us to receive information on the nature, mode and structure of food, the degree of motor activity, daily average energy consumption, caloric content and qualitative composition of the diet of students.

The obtained data allowed providing an analytical estimation of the diet of the energy and nutritional components.

\section{Results and Discussion}

Only about half of the students - boys $(43.75 \%$ who came from Africa and $42.7 \%$ of boys who came from Southern Asia) had a body mass corresponding to their age and gender. Among other students, the percentage of overweight young men was significantly higher: $56.25 \%$ came from African countries and $52.8 \%$ came from Asian countries. Of the girls, only $41.67 \%$ of the students who came from Africa, compared to $25 \%$ of girls from Southern Asia, had a standard body weight. Other students had significant deviations from the norm in terms of both excess and insufficient body weight (Table 1).

Table 1. Distribution of students who come to study from Africa, based on sex and food status $(M \pm m)$

\begin{tabular}{|c|c|c|c|}
\hline Gender, number & Estimation of food status & $\begin{array}{c}\text { BWI } \\
\mathrm{kg} / \mathrm{m} 2\end{array}$ & Interest \% \\
\hline \multirow{3}{*}{$\begin{array}{c}\text { Male } \\
\mathrm{n}=32\end{array}$} & Hypertrophy (BWI more than 23,90) & $26,29 \pm 0,9$ & 56,25 \\
\cline { 2 - 4 } & Normotrophy (BWI 18,5-23,8) & $21,48 \pm 0,5$ & 43,75 \\
\cline { 2 - 4 } & Hypotrophy (BWI less than 17,00) & - & - \\
\hline \multirow{3}{*}{$\begin{array}{c}\text { Women } \\
\text { n=24 }\end{array}$} & Hypertrophy (BWI more than 25,00) & $26,2 \pm 0,45$ & 25,00 \\
\cline { 2 - 4 } & Normotrophy (BWI 20,10-24,99) & $22,28 \pm 0,4$ & 41,67 \\
\cline { 2 - 4 } & Hypotrophy (BWI less than 20,00) & $18,07 \pm 0,36$ & 33,33 \\
\hline
\end{tabular}

Table 2. Distribution of students who come from South Asian countries, based on sex and nutritional status. $(M \pm m)$

\begin{tabular}{|c|c|c|c|}
\hline Gender, number & Estimation of food status & $\begin{array}{c}\text { BWI } \\
\mathrm{kg} / \mathrm{m} 2\end{array}$ & Interest \% \\
\hline \multirow{2}{*}{$\begin{array}{c}\text { Men } \\
\mathrm{n}=36\end{array}$} & Hypertrophy (BWI more than 23,90) & $25,32 \pm 0,6$ & 42,7 \\
\cline { 2 - 4 } & Normotrophy (BWI 18,5-23,8) & $21,63 \pm 0,5$ & 52,8 \\
\hline \multirow{3}{*}{$\begin{array}{c}\text { Women } \\
\text { n=8 }\end{array}$} & Hypotrophy (BWI less than 17,00) & $16,51 \pm 0,03$ & 4,5 \\
\cline { 2 - 4 } & Hypertrophy (BWI more than 25,00) & $25,40 \pm 0,003$ & 50 \\
\cline { 2 - 4 } & Normotrophy (BWI 20,10-24,99) & 24,20 & 25 \\
\cline { 2 - 4 } & Hypotrophy (BWI less than 20,00) & 17,00 & 25 \\
\hline
\end{tabular}


According to the study of the energy balance of the diet of foreign students, there were differences in the following: it was found that among the hypertrophied students who came from Africa. Only $5.3 \%$ compared with $11.9 \%$ of the students who came from South Asian countries p>0.01) consuming an excessive amount of kcal per day. It was found that $58 \%$ of normotrophic students who came to study from Africa, and 35\% of students who came to study from South Asia ( $p>0.01$ ) consume a physiological amount of kcal of a daily ration. In this group, there are only those students who have come to study from the countries of South Asia, the excess of caloric intake during the day. Inadequate amount of $\mathrm{kcal}$ in the diet consumes $17 \%$ of students who come to study from Southern Asia versus $41 \%$ of students who come to study from Africa, $(p>0.01)$. Among the students who came to study in Africa, hypotrophic students were distributed equally (50\% respectively) between normal and less than normal diet intake of calories per day, but as much as $81 \%$ of students who came to study from South Asian countries $(p>0,01)$, feed significantly less than regulatory requirements.

It was found that students who came to study from South Asia (when analyzing the nutritional composition of foods during the day), there is a deficiency of protein in $60 \%$ of cases, of those students who came to study from Africa in $26 \%$ of cases ( $>>0.01$ ). In addition, with a further comparison of these groups of students, significant significant results were obtained regarding the consumption of fats and carbohydrate imbalances (p>0.01).

The analysis of dietary calorie distributions over the course of a day has shown that students who come from Africa have better rates at the expense of nutrition-dependent students. It has been established that students who come from South Asian countries eat a significant deficit in calories during breakfast and lunch ( $p>0.01)$. At dinner, both groups of students exceed normative indicators of calorie distribution over the course of the day, but respondents who come from South Asian countries have significantly higher $(p>0.01)$ overeating rates during dinner.

For both groups of respondents, some difficulties were encountered in the formation of rational nutrition, which are related to everyday factors, including language and culture of nutrition.

Thus, we can assume that the nutrition and the two groups of foreign students are not rational, both in terms of quality and quantitative indicators, it is not balanced by structure, mode, protein, fat, carbohydrate ratio for both groups. But students who come to study from South Asia have considerably more problems in these matters.

During the interviews of the students of both groups, five most common causes of inappropriate food intake were identified:

- 1. Time: not enough time to prepare healthy food, especially for foreign students, due to a busy schedule;

- 2. Finance: it is difficult for many students to buy all the necessary products and vegetables, as well as everything necessary for the constant preparation of nutritious foods, because food is expensive, foreigners spend a lot of money on rental housing and other household needs;

- 3. Difference in Nutritional culture: from the students' point of view, it's hard to find anything good to eat, because most products are quite different from products in their countries, so it's difficult for them to eat what they are not accustomed to;

- 4. Language: Students go to markets and stores, it is difficult for them to get the products they need because they cannot ask or do not understand the language, and as a result they go to McDonald's or other fast foods and buy unhealthy food;

- 5. Weight: most girls do not want to fat, so in their quest to avoid foods that may make them look overweight, they become malnutrioned.

\section{Conclusion}

The study revealed that the nutritional routine of foreign students cannot be considered rational, based on both quantitative and qualitative indicators. The Most attention is drawn to the lack of caloric intake of food during the day, the decrease in protein intake and the inappropriate distribution of kcal among the main eating habits. The students lack a balance in proteins, carbohydrates and other microelements and macro-elements in their consumed foods. The research also revealed an inadequate physical exercise, and harmful habits among the students, which contributes to metabolic disorders in 
students, and poor performance among students. We recommend an educational regime to alert the students on the importance of healthy lifestyle. To conduct information companies among foreign students regarding the promotion of healthy eating, taking into account the data of the permanent place of residence. In the program of studying the Ukrainian language, it is expedient to include information on food products that are available in Ukraine and the particulars of their preparation and consumption.

\section{References}

1. Every year, the number of foreign students who want to obtain higher education in Ukraine is increasing [Electronic resource] Access mode: https://press.unian.ua/press/10144736-shchoroku- zrostaye-kilkist-inozemnih-studentiv-yaki-hochut-zdobuvativishchu-osvitu-v-ukrajini-video.html [in Ukrainian]

2. Bardov V.G (2008) Hygiene and ecology: study. - 719 p. [in

Russian]

3. Cyprian V.I. (2007) Hygiene of nutrition with the basics of T.1. - 340 p.; T. 2. - 422 p. [in Ukrainian]

4. Gorobei M.P. (2011) Problems of balanced nutrition of students. Pedagogics, psychology and medical-biological problems of physical education and sports. V. 10. - p. 5-9. [in Ukrainian]

5. Marushko Yu.V. (2013) Nutrition of student youth as a factor of a healthy lifestyle The Eastern European Journal of Public Health. p. 189-192. [inUkrainian]

6. Kovalchuk L.Y. (2017) Hygienic assessment of nutritional structure and adequacy of nutritional intake by freign students. Odessa Medical Journal. V.5 (163) - p. 53-58. [in Ukrainian]

7. Podrigalo L.V. (2015) Nutritionology. 300 p. [in Russian]

\title{
ГІГІЄНІЧНІ ОСОБЛИВОСТІ ХАРЧУВАННЯ ІНОЗЕМНИХ СТУ ДЕНТІВ-МЕДИКІВ 3 УРАХУВАННЯМ ЇХ НАЦІОНАЛЬНИХ КУЛЬТУР
}

\author{
Агву Чігборум Чарльз, Голубнича Г. І., Малярова Л. В.
}

Пошта для листування: charleschigborum@gmail.com

\begin{abstract}
Резюме: Під час навчання іноземні студенти проходять багато етапів прочесів адаптаиї до нових умов прожсивання, серед яких пристосування до кліматичних, соиіальних і харчових особливостей в Украйні. Іноземні студенти відчувають труднощіприформуваннісвогоращіону, слідуючинаціональнимтрадиціям. Вонинезавждиможутьправильнопідібрати аналоги звичних продуктів харчування, для приготувания ӥжі і все частіше харчуються у фаст-фудах.

Мета дослідження - запропонувати корекиійні заходи щодо харчового раиіону іноземних студентів-медиків $з$ урахуванням особливостей начіональних культур, які залежсать від географічного розташування краӥни прожсивання студентів.
\end{abstract}

Для досягнення мети були поставлені такі завдання: оцінити особливості харчового раиіону студентів, які приїхали навчатися з краӥн Африки та Південної Азії, з урахуванням гендерних особливостей; виявити фактори, які перешкоджають іноземним студентам-медикам слідувати приниппам рачіонального харчування; розробити пропозищї щодо корекиіїхарчової поведінки студентів.

Методи дослідження - соиіологічні (анкетування та інтерв'ювания), аналітичні, медико-статистичні, непараметричні методи математичної статистики.

В роботі представлені дані щодо кількісного та якісного складу харчових продуктів, які вэсивали респонденти протягом добиі режнимухарчування іноземних студентів-медиків, які приїхали вчитисяз країн Африки та Південної Азії.

Встановлено, що харчування студентів не є збалансованим за структурою, режимом, співвідноменню білків, жирів, вуглеводів в обохгрупах.

Автором показано основні бар'єри які, на думку студентів, перешкоджають їм рачіонально харчуватися. Отримания дані дозволили дати рекомендаиії по корекиії харчової поведінки іноземних студентів, які полягають у проведенні інформаційних компаній серед іноземних студентів з пропаганди здорового хариування, з урахуванням даних постійного місия прожсивання; донесенні до відомастудентів рекомендаиії ВООЗ щзодоздорового харчування; проведенні постійногомоніторингухарчовоїповедінки студентівз використаннямзапропонованої анкети.

Ключові слова: іноземні студенти, збалансоване харчування, режим харчування, кількісні та якісні показники, здоровий спосіб життя

\section{Інформація про авторів}

Агву Чігборум Чарльз -студент 3-го курсу Харківського національного університету імені В.Н. Каразіна, 61022, Україна, м. Харків, пл. Свободи, 6 charleschigborum@gmail.com

Голубнича Галина Ігорівна -асистент кафедри гігієни та соціальної медицини Харківського національного університету імені В.Н. Каразіна, 61022, Україна, м. Харків, пл. Свободи, 6; молодший науковий співробітник відділення наукової організації медичної допомоги школярам і підліткам ДУ «Інститут охорони здоров'я дітей та підлітків Національної академії медичних наук України» 61153 , Україна, м. Харків, пр. Ювілейний, 52а, galj6566@gmail.com

https://orcid.org/0000-0001-7832-20591 Малярова Людмила Володимирівна асистент кафедри гігієни та соціальної, медицини Харківського національного університету імені В.Н. Каразіна, 61022 Україна, м. Харків, пл. Свободи, 6 l.v.maliarova@karazin.ua, https://orcid.org/ 0000-0002-7902-7016 


\title{
ГИГИЕНИЧЕСКИЕ ОСОБЕННОСТИ ПИТАНИЯ ИНОСТРАННЫХ СТУДЕНТОВ- МЕДИКОВ С УЧЕТОМ ИХ НАЦИОНАЛЬНЫХ КУЛЬТУР
}

\author{
Агву Чигборум Чарльз, Голубничая Г. И., Малярова Л. В.
}

Пошта для листування: charleschigborum@gmail.com

Резюме. Во время учебы иностранные студенты проходят много этапов процессов адаптации к новым условиям обитания, среди которых приспособления $\kappa$ климатическим, социальным и пищевых особенностей в Украине. Иностранные студенты испытывают трудности при формировании своего рациона, следуя начиональным традициям. Они не всегда могут правильно подобрать аналоги привычных продуктов питания, для приготовления пищи и все чаще питаются в фастфудах.

Цель исследования - предложить коррекционные мероприятия по улутьшению пищевого рациона иностранных студентов-медиков с учетом особенностей начиональных культур, которые зависят от географического расположения страны проживания студентов.

Для достижения иели были поставлены следующие задачи: оценить особенности пищевого рациона студентов, приехавших учиться из стран Африки и Южной Азии, с учетом гендерных особенностей; вылявить факторы, которые препятствуют иностранным студентам-медикам следовать принципам рационального питания; разработать предложения по коррекции пищевого поведения студентов.

Методы исследования - сочиологические (анкетирование и интервьюирование), аналитические, медикостатистические, непараметрические методы математической статистики.

В работе представлены данные по количественному и качественному составу пищевых продуктов, которые употребляли респонденты в течение суток и режима питания иностранных студентовмедиков, которые приехали учиться из стран Африки и Южной Азии.

Установлено, что питание студентов не является сбалансированным по структуре, режимом, соотношению белков, жиров, углеводов в обеих группах.

Автором показаны основные барьеры, которые, по мнению студентов, препятствуют им рационально питаться.

Получение данные позволили дать рекомендации по коррекции пищевого поведения иностранных студентов, которые заключаются в проведении информационных компаний среди иностранных студентов по пропаганде здорового питания, с учетом данных постоянного места проживания; донесении до сведения студентов рекомендации ВОЗ по здоровому питанию; проведении постоянного мониторинга пищевого поведения студентов из использования предложенной анкеты.

Ключевые слова: иностранные студенты, сбалансированное питание, режим питания, количественные и качественные показатели, здоровый образ жизни

\section{Інформація про авторів}

Агву Чигборум Чарльз - студент 3-го

курса Харьковского национального

университета имени В.Н. Каразина

61022, Украина, г. Харьков, пл.

Свободы, 6charleschigborum@gmail.com

Голубничая Галина Игоревна ассистент кафедры гигиены и социальной медицины Харьковского национального университета имени В.Н. Каразина, 61022, Украина, г. Харьков, пл. Свободы, 6; младший научный сотрудник отделения научной организации медицинской помощи школьникам и подросткам ГУ «Институт охраны здоровья детей и подростков Национальной академии медицинских наук Украины», 61153 Украина, г. Харьков, пр-т. Юбилейный, 52a, $\quad$ galj6566@gmail.com, https://orcid.org/0000-0001-7832-20591
Малярова Людмила Владимировна, ассистент кафедры гигиены и социальной медицины Харьковского национального университета имени В.Н. Каразина, 61022, Україна, м. Харків, пл. Свободи, 6, l.v.maliarova@karazin.ua, https://orcid.org/ 0000-0002-7902-7016

Conflicts of interest: author has no conflict of interest to declare.

Конфлікт інтересів: відсутній.

Конфликт интересов: отсутствует 